\title{
Adieu to parting Editor in Chief and pioneering scientist Dr. Joyce Bischoff
}

\author{
Juan M. Melero-Martin ${ }^{1} \cdot$ Andrew C. Dudley ${ }^{2} \cdot$ Arjan W. Griffioen $^{3}$
}

Published online: 11 April 2021

(c) The Author(s), under exclusive licence to Springer Nature B.V. 2021

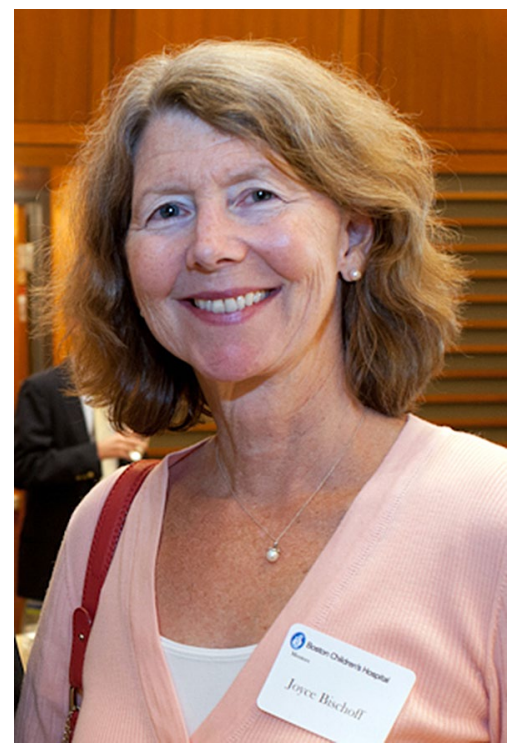

For 16 years, Dr. Joyce Bischoff served the journal Angiogenesis as an Editor in Chief. Some time ago, she decided to step down from this duty in January 2021. It is time to take an admiring look back at her scientific accomplishments and dedication to helping establish the journal.

Joyce Bischoff, $\mathrm{PhD}$ was trained in biochemistry and molecular biology. She studied asparagine-linked oligosaccharide processing under Dr. Rosalind Kornfeld at Washington University in St. Louis and receptor biology with Dr.

Arjan W. Griffioen

a.griffioen@amsterdamumc.nl

1 Department of Cardiac Surgery, Boston Children's Hospital, Harvard Medical School, Boston, MA 02115, USA

2 Department of Microbiology, Immunology, and Cancer Biology, The University of Virginia, \& The Emily Couric Cancer Center, Charlottesville, VA 22908, USA

3 Angiogenesis Laboratory, Department of Medical Oncology, Cancer Center Amsterdam, Amsterdam University Medical Center, Vrije Universiteit Amsterdam, Amsterdam, The Netherlands
Harvey Lodish at the Whitehead Institute for Biomedical Research in Cambridge, MA. She was then recruited by the late Dr. Judah Folkman to join the Vascular Biology Program's dynamic faculty at Boston Children's Hospital. Her initial work in the early 1990s provided novel insights on the critical role that endothelial cell adhesion molecules play in angiogenesis and the singular importance of E-Selectin [1]. However, she quickly expanded her investigations beyond adhesion molecules. Unusual for early-stage investigators of her generation, she promptly diversified her research into several different areas of vascular biology. Joyce was also an early adapter of the diverse, multidisciplinary team concept, with a routine presence of biologists, physicians, and engineers from all around the world working together in her lab. Undoubtedly, this diversification came to define and enable her broad impact on vascular biology research in the decades that followed.

In her first decade at Boston Children's Hospital, Joyce established three lines of investigation that remain active to date. First, she became intrigued by infantile hemangioma (IH), a unique vascular overgrowth of infancy. Joyce made several seminal contributions that helped unravel the cellular and molecular mechanisms governing the progression of IH. Her lab discovered a hemangioma stem cell (HemSC) in proliferating human $\mathrm{IH}$ and showed that these HemSCs could recapitulate the formation of hemangioma-like vascular lesions upon implantation in mice [2]. This discovery was a significant breakthrough that transformed the conventional view of IH as an endothelial tumor driven by angiogenesis to a stem cell tumor driven by de novo vessel formation, leading to a profound vascular overgrowth. This insight was instrumental in elucidating the mechanisms of action of currently used drugs and identifying new therapeutic options for IH. Indeed, Joyce's research showed that corticosteroids (a traditional IH therapy) suppress VEGF-A produced by HemSCs, which in turn is sufficient to block blood vessel formation by these cells [3]. Also, her group discovered that rapamycin reduces HemSC stem-ness and vessel forming 
ability [4], an insight that instigated several clinical trials for topical rapamycin treatment of IH. More recently, her lab identified a novel mechanism by which another drug, propranolol, reduces vascular overgrowth in IH [5]. This progression from basic to translational science continues to be a hallmark of Joyce's approach to research.

A second major research area that Joyce established was the investigation of endothelial progenitor cells (initially termed EPCs but now widely referred to as endothelial colony-forming cells or ECFCs). The identification of circulating ECFCs in human peripheral blood had only occurred in the late 1990s; yet, by 2001, Joyce's lab published the first translational demonstration that ECFCs could be isolated from blood samples and used to line small-diameter arterial grafts [6]. This pioneering study was highly influential as it demonstrated that autologous endothelial cells could be easily obtained and used for vascular tissue engineering, regeneration, and repair. Moreover, her lab established that human ECFCs have a uniquely robust capacity to selfassemble into perfused vascular networks in vivo [7, 8]. Over the last two decades, her foundational work on ECFCs has inspired numerous investigations in the pursuit of building functional blood vessels.

Joyce's interest expanded to heart valve development and the plasticity of endothelial cells in cardiac valves. Her lab showed that adult cardiac valve endothelial cells retain critical pathways used during valve development, most notably endothelial to mesenchymal transition (EndMT) [9]. She established the concept of basal levels of EndMT in healthy valves contributing to valve leaflets' regeneration by replenishing interstitial cells [10]. Indeed, Joyce and her collaborators demonstrated that reactivation of EndMT in valve leaflets is a dynamic mechanism for adaptation to pathophysiologic changes due to cardiovascular disease, a concept that has been substantiated in other laboratories. Once more, Joyce's work in this area has concrete translational implications-her group showed that losartan, an antihypertensive drug, could mitigate myocardial infarction-induced EndMT and valve leaflet thickening, suggesting potential for therapy $[11,12]$.

In recent years, Joyce's research has intensified around studying various types of vascular abnormalities, including capillary, lymphatic, and venous malformations, where new therapies are badly needed. Her research has transformed our understanding of the cellular and molecular basis behind vascular malformations and has led to new models to identify therapies that target aberrant vascular development [13]. Joyce currently investigates the genetic basis of vascular malformations, and her group has identified a few somatic missense mutations associated with various types of capillary malformations, including Sturge-Weber syndrome [14, 15].
In all, the depth and breadth of Joyce's contributions to angiogenesis and vascular biology research are immense. This influence expands to her trainees, to whom she often becomes a life-long friend and supporter. As a mentor, Joyce epitomizes the notion of leading by example; she always passionately embraces scientific rigor, but with a uniquely personal and kind approach, attending to each person's needs in her lab. Indeed, a testament to Joyce's legacy to science is the research emanating from her many trainees' independent laboratories.

In 2004, Joyce joined Angiogenesis as Editor in Chief. When she was asked to take on this assignment, she agreed because of the opportunity to better serve the scientific community at large. Starting a journal is never easy, and in those first years the ride with Angiogenesis was rough. The combination of lack of an impact factor while at the same time trying to attract high-quality, original research contributions was a huge challenge. However, with the support of many in the scientific fields of angiogenesis and vascular biology, Angiogenesis prevailed and began blossoming to the level where it is now. It is fair to say that the current high impact of the journal is due, in large part, thanks to the exemplary scientific quality and the dedication and guidance of our reviewers and editorial board; in addition, Joyce's own excellent scientific contributions to the journal have no doubt played a large role in helping the journal to grow and prosper [13, 16-18]. We are very thankful for Joyce's vision and long-term dedication to Angiogenesis.

\section{References}

1. Bischoff J (1997) Cell adhesion and angiogenesis. J Clin Invest 99(3):373-376. https://doi.org/10.1172/JCI119168

2. Khan ZA, Boscolo E, Picard A, Psutka S, Melero-Martin JM, Bartch TC, Mulliken JB, Bischoff J (2008) Multipotential stem cells recapitulate human infantile hemangioma in immunodeficient mice. J Clin Invest 118(7):2592-2599. https://doi.org/10. 1172/JCI33493

3. Greenberger S, Boscolo E, Adini I, Mulliken JB, Bischoff J (2010) Corticosteroid suppression of VEGF-A in infantile hemangiomaderived stem cells. N Engl J Med 362(11):1005-1013. https://doi. org/10.1056/NEJMoa0903036

4. Greenberger S, Yuan S, Walsh LA, Boscolo E, Kang KT, Matthews B, Mulliken JB, Bischoff J (2011) Rapamycin suppresses self-renewal and vasculogenic potential of stem cells isolated from infantile hemangioma. J Invest Dermatol 131(12):2467-2476. https://doi.org/10.1038/jid.2011.300

5. Overman J, Fontaine F, Wylie-Sears J, Moustaqil M, Huang L, Meurer M, Chiang IK, Lesieur E, Patel J, Zuegg J, Pasquier E, Sierecki E, Gambin Y, Hamdan M, Khosrotehrani K, Andelfinger G, Bischoff J, Francois M (2019) R-propranolol is a small molecule inhibitor of the SOX18 transcription factor in a rare vascular 
syndrome and hemangioma. Elife. https://doi.org/10.7554/eLife. 43026

6. Kaushal S, Amiel GE, Guleserian KJ, Shapira OM, Perry T, Sutherland FW, Rabkin E, Moran AM, Schoen FJ, Atala A, Soker S, Bischoff J, Mayer JE Jr (2001) Functional small-diameter neovessels created using endothelial progenitor cells expanded ex vivo. Nat Med 7(9):1035-1040. https://doi.org/10.1038/ nm0901-1035

7. Melero-Martin JM, De Obaldia ME, Kang SY, Khan ZA, Yuan L, Oettgen P, Bischoff J (2008) Engineering robust and functional vascular networks in vivo with human adult and cord bloodderived progenitor cells. Circ Res 103(2):194-202. https://doi. org/10.1161/CIRCRESAHA.108.178590

8. Melero-Martin JM, Khan ZA, Picard A, Wu X, Paruchuri S, Bischoff J (2007) In vivo vasculogenic potential of human bloodderived endothelial progenitor cells. Blood 109(11):4761-4768. https://doi.org/10.1182/blood-2006-12-062471

9. Paruchuri S, Yang JH, Aikawa E, Melero-Martin JM, Khan ZA, Loukogeorgakis S, Schoen FJ, Bischoff J (2006) Human pulmonary valve progenitor cells exhibit endothelial/mesenchymal plasticity in response to vascular endothelial growth factor-A and transforming growth factor-beta2. Circ Res 99(8):861-869. https://doi.org/10.1161/01.RES.0000245188.41002.2c

10. Bischoff J (2019) Endothelial-to-mesenchymal transition. Circ Res 124(8):1163-1165. https://doi.org/10.1161/CIRCRESAHA.119. 314813

11. Bartko PE, Dal-Bianco JP, Guerrero JL, Beaudoin J, Szymanski C, Kim DH, Seybolt MM, Handschumacher MD, Sullivan S, Garcia ML, Titus JS, Wylie-Sears J, Irvin WS, Messas E, Hagege AA, Carpentier A, Aikawa E, Bischoff J, Levine RA, Leducq Transatlantic Mitral N (2017) Effect of losartan on mitral valve changes after myocardial infarction. J Am Coll Cardiol 70(10):1232-1244. https://doi.org/10.1016/j.jacc.2017.07.734
12. Wylie-Sears J, Levine RA, Bischoff J (2014) Losartan inhibits endothelial-to-mesenchymal transformation in mitral valve endothelial cells by blocking transforming growth factor-betainduced phosphorylation of ERK. Biochem Biophys Res Commun 446(4):870-875. https://doi.org/10.1016/j.bbrc.2014.03.014

13. Boscolo E, Coma S, Luks VL, Greene AK, Klagsbrun M, Warman ML, Bischoff J (2015) AKT hyper-phosphorylation associated with PI3K mutations in lymphatic endothelial cells from a patient with lymphatic malformation. Angiogenesis 18(2):151162. https://doi.org/10.1007/s10456-014-9453-2

14. Huang L, Couto JA, Pinto A, Alexandrescu S, Madsen JR, Greene AK, Sahin M, Bischoff J (2017) Somatic GNAQ mutation is enriched in brain endothelial cells in Sturge-Weber syndrome. Pediatr Neurol 67:59-63. https://doi.org/10.1016/j.pediatrneurol. 2016.10.010

15. Bichsel C, Bischoff J (2019) A somatic missense mutation in GNAQ causes capillary malformation. Curr Opin Hematol 26(3):179-184. https://doi.org/10.1097/MOH.0000000000000500

16. Boscolo E, Bischoff $\mathbf{J}$ (2009) Vasculogenesis in infantile hemangioma. Angiogenesis 12(2):197-207. https://doi.org/10.1007/ s10456-009-9148-2

17. Greenberger S, Adini I, Boscolo E, Mulliken JB, Bischoff J (2010) Targeting NF-kappaB in infantile hemangioma-derived stem cells reduces VEGF-A expression. Angiogenesis 13(4):327-335. https://doi.org/10.1007/s 10456-010-9189-6

18. Kang KT, Coggins M, Xiao C, Rosenzweig A, Bischoff J (2013) Human vasculogenic cells form functional blood vessels and mitigate adverse remodeling after ischemia reperfusion injury in rats. Angiogenesis 16(4):773-784. https://doi.org/10.1007/ s10456-013-9354-9

Publisher's Note Springer Nature remains neutral with regard to jurisdictional claims in published maps and institutional affiliations. 